\title{
Stakeholder Perceptions of Policy Tools in Support of Sustainable Food Consumption in Europe: Policy Implications
}

\author{
Nína M. Saviolidis ${ }^{1, *(\mathbb{D}}$, Gudrun Olafsdottir ${ }^{1}{ }^{(\mathbb{D}}$, Mariana Nicolau ${ }^{2}$, Antonella Samoggia ${ }^{3}{ }^{(\mathbb{D}}$, \\ Elise Huber ${ }^{4}$, Laura Brimont ${ }^{4}$, Matthew Gorton ${ }^{5}{ }^{\circ}$, David von Berlepsch ${ }^{6}{ }^{\circ}$, \\ Hildigunnur Sigurdardottir ${ }^{7}{ }^{\mathbb{C}}$, Margherita Del Prete ${ }^{3}{ }^{(0)}$, Cristina Fedato ${ }^{2}$, Pierre-Marie Aubert ${ }^{4}$ \\ and Sigurdur G. Bogason ${ }^{1}$ \\ 1 Applied Supply Chain Systems Research Group, University of Iceland, Dunhagi 5, 107 Reykjavík, Iceland; \\ go@hi.is (G.O.); sigboga@hi.is (S.G.B.) \\ 2 Collaborating Centre on Sustainable Consumption and Production, Hagenauer Strasse 30, \\ 42107 Wuppertal, Germany; mariana.nicolau@scp-centre.org (M.N.); cristina.fedato@scp-centre.org (C.F.) \\ 3 Department of Agricultural and Food Sciences, University of Bologna, Viale Fanin 50, 40127 Bologna, Italy; \\ antonella.samoggia@unibo.it (A.S.); margherita.delprete5@unibo.it (M.D.P.) \\ 4 Institute for Sustainable Development and International Relations (IDDRI), 41 rue du Four, \\ 75006 Paris, France; elise.huber@iddri.org (E.H.); laura.brimont@iddri.org (L.B.); \\ pierremarie.aubert@iddri.org (P.-M.A.) \\ 5 Business School, Newcastle University, 5 Barrack Road, Newcastle upon Tyne NE1 4SE, UK; \\ matthew.gorton@ncl.ac.uk \\ 6 Vlerick Business School, Ghent University, Sint-Pietersnieuwstraat 25, B-9000 Ghent, Belgium; \\ david.schamari@ugent.be \\ 7 Markmar, Dunhagi 5, 107 Reykjavík, Iceland; hilda@markmar.is \\ * Correspondence: nms@hi.is
}

Received: 5 August 2020; Accepted: 29 August 2020; Published: 2 September 2020

check for updates

\begin{abstract}
Transitioning agri-food systems towards increased sustainability and resilience requires that attention be paid to sustainable food consumption policies. Policy-making processes often require the engagement and acceptance of key stakeholders. This study analyses stakeholders' solutions for creating sustainable agri-food systems, through interviews with a broad range of stakeholders including food value chain actors, non-governmental organizations, governmental institutions, research institutions and academic experts. The study draws on 38 in-depth, semi-structured interviews conducted in four European countries: France, Iceland, Italy and the UK, as well as three interviews with high-level EU experts. The interviewees' solutions were analysed according to a five-category typology of policy tools, encompassing direct activity regulations, and market-based, knowledge-based, governance and strategic policy tools. Most of the identified solutions were located in the strategic tools category, reflecting shared recognition of the need to integrate food policy to achieve long-term goals. Emerging solutions-those which were most commonly identified among the different national contexts-were then used to derive empirically-grounded and more universally applicable recommendations for the advancement of sustainable food consumption policies.
\end{abstract}

Keywords: sustainable food consumption; agri-food systems; transition; stakeholders; semi-structured interviews; policy tools

\section{Introduction}

There is growing recognition that contemporary agri-food systems are neither sustainable nor resilient, and that they are in need of profound transformation in order to meet multiple challenges [1]. 
The challenges faced by agri-food systems are complex and interconnected. Food is a cross-cutting issue implicated in multidimensional sustainability, such as environment, health, food security and socio-economic issues, amidst growing demand driven by population growth and increased affluence. Food production, trade and consumption both exacerbate and are affected by mounting environmental challenges, such as climate change, biodiversity loss and resource depletion (e.g., soils and water) [2,3]. The need to transform agri-food systems to address these challenges has been highlighted in various socio-economic and political agendas by academia and other institutional actors recently at both the international and regional levels; e.g., [1,3-6]. The food system concept has become important in both research and in policy discourse, as it addresses the complexity of food as a cross-cutting issue [7]. The Food and Agriculture Organization of the United Nations (FAO) [8] defines a food system as "the entire range of actors and their interlinked value-adding activities involved in the production, aggregation, processing, distribution, consumption and disposal of food products that originate from agriculture, forestry or fisheries, and parts of the broader economic, societal and natural environments in which they are embedded" (p. 1).

The concept of a food system highlights not only the complex processes of producing, transporting, consuming and disposing of food but also the multitude of actors involved and the diverse impacts that result from each of these processes. Making agri-food systems more sustainable will require the integration of policies at several different levels-local, national, regional and international-with the aim of meeting common goals. It will also require the integration of policies from different policy spheres, such as agriculture, climate and the environment, health, and worker's rights. A coherent and holistic vision is necessary to guide institutions towards sustainability [7]. For these requirements to be realized, it is necessary to examine the role of different actors in the agri-food system and take into account their perspectives on the availability and feasibility of various policy options [9].

\section{Food and Sustainable Consumption and Production Patterns}

The need to shift consumption and production patterns towards sustainability was first recognized internationally at the 1992 Earth summit in Rio de Janeiro [10]. Until that time, the emphasis had been almost exclusively on the production side, and consumption had not been adequately addressed by policy makers [11]. Today, nearly three decades later, Sustainable Consumption and Production (SCP) are an integral part of the Sustainable Development Goals (SDGs) (i.e., goal 12; responsible consumption and production) [12]. The inclusion of consumption and production within a single goal points to the recognition of their complex interaction, and the importance of addressing both concurrently in an integrated and holistic manner. Food, along with water and energy, were highlighted as integral issues for the achievement of goal 12 [12].

As a crosscutting issue, food is related to all of the SDGs, both directly and indirectly [13,14]. The EAT Lancet Commission's report identified food system transformation as essential to meeting the SDGs, as well as the Paris agreement on climate change. It enumerated two targets and five strategies for achieving the goals of healthy diets and sustainable agri-food systems. Addressing the consumption side, the report proposed that sustainable diets are an important component of agri-food systems' transformation can deliver benefits to human health and simultaneously ensure that food systems do not compromise environmental sustainability. Sustainable diets, alongside improvements in food production practices and reductions in food loss and waste, were projected as three of the most impactful ways to achieve healthy and sustainable agri-food systems [3].

It is increasingly recognized that the consumer is a limited agent of change due to the complexity of highly global food systems, human cognition and behaviour, and the structural characteristics of the food environment $[15,16]$. However, the recognition of this in policy agendas remains limited [17]. Policies that support sustainable food consumption without heavily relying on the consumer solely as an agent of change are crucial for the transition to more sustainable food systems [14].

Many recent food policy documents and reports include the aim of a transition to sustainable food systems, e.g., $[3,18,19]$, reflecting the widespread adoption of the concept in the policy domain. The 
concept of sustainability transitions refers to the need to bring about the "large-scale societal changes deemed necessary to solve grand societal challenges" [20] (p. 600). In the last two decades there has been a wealth of academic studies published on sustainability transitions in general [20,21], and within the context of agri-food systems more specifically [22,23]. Research on agri-food system transitions, as opposed to energy and mobility transitions, is more recent, but is developing at a fast rate. However, research gaps have been identified where studies have tended to place less emphasis on the role of Food Value Chain (FVC) actors and civil society, and are instead more frequently based on single case studies [22].

Though there is broad agreement on the need for a transition, many different transition pathways have been proposed based on different conceptualisations of key issues [24] and the actors advocating change [25]. Often, practitioner viewpoints have been ignored, with a danger of developing policies that are unworkable or which have unintended negative consequences [26]. Sustainability transitions require that attention be paid to the context, including the region, sectoral elements, the policy domain and cultural characteristics [22]. The different underlying conceptualizations, ambitions and goals of the different actors involved in food systems, as well as the complexity of their interactions and interdependencies, are also crucial factors to take into account [9]. Broad stakeholder consultation and engagement are thus essential to the process of delineating solution pathways to more sustainable agri-food systems.

This study was part of a larger Horizon 2020 project called VALUMICS, the general aim of which was to provide tools and approaches to enable decision makers to evaluate the impact of strategic and operational policies aimed at enhancing fairness, integrity, and resilience in future scenarios of sustainable Food Value Chains (FVCs). This study's specific aim is to explore and analyse stakeholders' proposed solutions for creating sustainable agri-food systems based on findings from in-depth interviews, in order to identify policy recommendations.

The paper is structured as follows: Section 2 presents the methods, while Section 3 details the findings. Section 4 discusses the main findings and presents policy recommendations. Finally, Section 5 is the study's overall conclusion.

\section{Materials and Methods}

\subsection{Semi-Structured Interviews}

A total of 38 semi-structured interviews were conducted with 40 experts (in two of the interviews there were two participants) in: France (10), Iceland (16), Italy (6) and the UK (3), including interviews with EU-level experts (3), during September-November 2019. Each interview lasted approximately $60 \mathrm{~min}$ on average, with a total of approximately $40 \mathrm{~h}$ of recorded material. Most interviews were conducted face to face, except for two, which were conducted via a web conferencing platform due to practical considerations. The interviews followed a common format and a structured interview guide developed by the authors of this study. The interview guide comprised three sections focusing on three distinct topics: (1) the drivers and motivations of mainstream food consumption behaviour, (2) the role and influence of consumers on sustainable food value chains and, (3) potential solutions to enable more sustainable food consumption behaviour. This study was largely based on the discussions ensuing from Section 3 of the framework.

The interviews were recorded, and detailed summaries-including a selection of quotationswere compiled for each interview. All summaries and direct quotations were translated into English using standard back-translation techniques [27], except for the UK interviews and interviews with EU-level experts, which were conducted in English. Practical considerations precluded the full transcription of the interviews, but the compiled summaries were based on the recorded sessions and extensive note taking by the interviewers. Participants were assigned pseudonyms and are only referred to by those in the analysis in order to preserve their anonymity. The pseudonyms are composed of a number followed by the national code for easy reference (see Appendix A). All of the participants 
received a participant information sheet and were required to sign a consent form detailing their rights, as required by EU Horizon 2020 regulations on data management concerning ethical and societal aspects [28].

\subsection{Participants}

Participant selection in this study was based on purposive sampling [29]. Participants were chosen based on their position and knowledge in their company/organization. For the private sector, CEOs and high-level managers (i.e., senior decision-making roles) were included for their expert knowledge of market trends and corporate decision-making and management. Elite interviews can be challenging-e.g., due to issues of positionality, power and restricted access-but they provide important insights into high-level decision-making processes [30]. For other stakeholders, participants were included based on their expertise and involvement in food systems; e.g., policy-makers directly involved in food policy-making. In some cases, interviewees recommended other experts in order to strengthen the inclusion of key informants in the study (snowball sampling).

The inclusion of stakeholders representing all of the key actors in European agri-food value chains was pursued. The authors had access to a stakeholder platform as part of the larger project (VALUMICS), and were, therefore, able to secure interviews with elites. In the few cases where stakeholders declined participation, they recommended another potential participant to take their place. Reasons for declining where often related to practical and time constraints on the part of the interviewee and, occasionally, the interviewers themselves. For example, one stakeholder responded after the analysis of the interviews had been undertaken and, therefore, their participation had to be declined. A positive and somewhat surprising aspect of this process was the relative ease of access to interviewees and their willingness to participate. This may be an indication that the topic of sustainability in food systems is high on the agenda of both FVC actors and other stakeholders.

The process resulted in a final pool of interviewees, which included policymakers, business associations, individual companies, consumer organizations, consultancies, Non-Governmental Organizations (NGOs) and academic experts (relating to health, nutrition and behavioural science). Three interviews with EU-level experts provided a higher-level perspective. Table A1 in Appendix A details the relevant characteristics of the participants in this study, including the position of their organization in the value chain, their own role in it, and the context (national or EU-level).

\subsection{Analysis}

Drawing on Galli, Favilli, D'Amico and Brunori's [31] typology, five broad food policy categories were utilized to analyse and structure the findings from the in-depth stakeholder interviews. Figure 1, below, presents an overview and brief explanation of each category.

The interview data were coded via the analytical method of constant comparisons, resulting in emerging commonalities and differences in terms of the discussed solutions [32]. All of the recommended solutions mentioned by participants were subsequently categorized using the policy tools typology based on Galli et al. [31] (see Figure 1). Policy tools are the means by which policy implementation is achieved [31], and categorizing the findings through this typology highlights the range and popularity of the proposed solutions. Galli et al. [31] typology was deemed most appropriate for this study due to its broad inclusion of different types of policy tools. Early in the interviewing process, it emerged that the proposed solutions were wide-ranging, and a typology was sought that would reflect the range while at the same time classifying solutions in a comprehensive yet accessible manner. The identified policy solutions were categorised from most commonly mentioned to least commonly mentioned in each country, in order to identify commonalities and differences across contexts. The use of standard country codes aided the cross-context analysis. 


\begin{tabular}{|c|c|}
\hline $\begin{array}{l}\text { Direct activity } \\
\text { regulation }\end{array}$ & $\begin{array}{l}\text { - e.g., limitations, quotas, prohibitions, } \\
\text { authorizations etc. }\end{array}$ \\
\hline Market-based & $\begin{array}{l}\text { e.g., subsidies, loans, guarantees, } \\
\text { certification schemes, taxes, charges, fees, } \\
\text { fines etc. }\end{array}$ \\
\hline Knowledge-based & $\begin{array}{l}\text { - e.g., information, communication, } \\
\text { research, education, etc. }\end{array}$ \\
\hline Governance & $\begin{array}{l}\text { - role and distribution of different actors' } \\
\text { responsibilities e.g., business, governmental } \\
\text { institutions, NGOs, consumers etc. }\end{array}$ \\
\hline Strategic & $\begin{array}{l}\text { - e.g., framework conventions, guidelines, } \\
\text { strategic action plans, and roadmaps }\end{array}$ \\
\hline
\end{tabular}

Figure 1. Classification of policy tools, with examples (adapted from [31]).

The reported findings in Section 3 focus on commonalities, in order to provide more universally applicable recommendations. Though not discussed, less commonly identified solutions in Tables 1-5 detail a range of policies that are more context-specific. For example, among Icelandic participants, a common solution was the provision of cheaper electricity for greenhouses as a way of increasing the production of vegetables.

The focus of the analysis is at the European level regarding stakeholders' insights into possible solutions for more sustainable food systems. As such, the resulting policy recommendations are firmly rooted in practitioner perspectives. Semi-structured interviews enable a discussion on set topics and guarantee that all of the participants engage with them. However, they are also flexible enough to allow new topics to emerge based on what each participant places greater importance upon [29]. The emergence of new topics is an advantage of qualitative research in general, as it encourages researchers to shed their own preconceptions about the topic under investigation and explore different perspectives in greater depth [32].

\section{Findings}

Several proposals for transitions to more sustainable food consumption emerged from the interviews. In this section, the most commonly identified proposals are presented, and illustrative direct quotations by the interviewees are reported in the text. Tables 1-5 list all of the proposals, including those that were least commonly identified. The subsection titles below constitute higher-order themes, which correspond to the policy tools in the order that they are presented in Figure 1. It should be noted that the sequence of higher-order themes is presented in this way for ease of reference and does not represent prioritization by either the participants or the authors. In Section 4, the findings are discussed and specific policy recommendations are presented based on the findings from the stakeholder interviews.

\subsection{Integrate Policies on Environmental Sustainability for More Effective Food System Management}

According to participants, solution pathways should include regulations and incentives that place sustainability amongst the top priorities of food systems' management (see Table 1). 
Table 1. Possible solutions identified by stakeholders classified as direct activity regulation policy tools.

\begin{tabular}{cc}
\hline Policy Tools & Proposed Solutions by Stakeholders \\
\hline & $\begin{array}{r}\text { EU-level mandatory regulations imposed on all for a level playing field (IT, UK) } \\
\text { Reduce fertilizer and pesticide use (IT, UK) }\end{array}$ \\
\cline { 2 - 3 } Direct activity regulation & Less Commonly Identified \\
\cline { 2 - 3 } & $\begin{array}{c}\text { Ban production of certain unsustainable products (EU) } \\
\text { Enforce minimum requirements for Extended Producer Responsibility (EU) } \\
\text { Make product reformulation for nutritional benefits mandatory (FR) } \\
\text { Reduce air transport of food (FR) } \\
\text { Ban disposable plastics (IT) } \\
\text { Ban the landfilling of biodegradable waste to reduce food loss/waste (IS) } \\
\text { Improve food inspection to ensure food safety and quality (IS) } \\
\text { Abolish the right for retailers to return expired food (IS) } \\
\text { Implement fixed production quotas (UK) } \\
\text { Enforce high quality standards (UK) }\end{array}$ \\
\hline
\end{tabular}

Some participants argued that, despite the importance of prioritizing sustainability objectives in the management of food systems, such a shift in prioritization would have implications for food prices, which limits uptake:

Consumers will not push for it. So why would any company change a running system when the willingness to pay and the ability to pay is not supported by the customers' demand on a broad scale? (P19-UK)

Efficiency and sustainability were often discussed as competing goals that are not easy to reconcile, especially with many consumers being unwilling to pay price premiums for more sustainable products.

Real change can only be generated by the EU. Until certain management practices are allowed, it is difficult to behave more sustainably because everyone else can be more economically competitive. (P23-IT)

Emphasis was therefore placed on the need for EU-level regulations to ensure a level playing field for all.

Implement sustainability by imposing strict rules where products have to comply with the law. If not, then we might lose democratic stability in our countries. Law is the only way to put all in the same position bound by law. That would account for retailers, producers and consumers in the same way. (P19-UK)

A variety of more specific regulations were proposed by participants to ameliorate the environmental impacts from food systems, ranging from banning the disposal of biodegradable waste via landfill, imposing plastic packaging bans, and making sustainable agriculture mandatory (see Table 1). Reducing fertilizer and pesticide use through regulation was the only specific regulation to emerge in more than one of the countries where the interviews were conducted. In both cases, it was related to their impacts on soils and the importance of protecting them for agricultural production.

Views were, however, mixed regarding whether new regulatory frameworks should be based on coercive measures or voluntary schemes. Some of the participants highlighted the value of the latter:

This is a mandatory step that companies will undergo in the long run. If you want to speed up the transition you can do it in a coercive or a proactive way. In my opinion, it is better to encourage than to mandate. (P22-IT) 


\subsection{Utilize Market Incentives in Support of Sustainable Food Consumption}

Many participants endorsed the use of various market tools to advance sustainability goals (see Table 2). Among the most commonly mentioned were public and green procurement, and the use of ecolabels and certification schemes.

Table 2. Possible solutions identified by stakeholders classified as market-based tools.

\begin{tabular}{cc}
\hline Policy Tools & Proposed Solutions by Stakeholders \\
\hline \multirow{3}{*}{ Market-based tools } & $\begin{array}{c}\text { Public and green procurement (FR, IS, EU) } \\
\text { Certification schemes and ecolabels (FR, IS, IT) }\end{array}$ \\
\cline { 2 - 2 } & Less Commonly Identified \\
\cline { 2 - 2 } & Taxation to encourage sustainable production and consumption (IS, EU) \\
Price guarantees (IT, UK) \\
Increase subsidies for organic farmers (FR) \\
Decrease the price of electricity for greenhouse vegetable growers (IS) \\
Reduce subsidies for meat production (IS)
\end{tabular}

Several participants maintained that the public sector also has an important role to play in driving sustainable consumption, including from the demand side (P31-FR). Policies to encourage sustainable food systems have until recently been mainly geared towards the supply side (CAP, Programme Ambition Bio, etc.) and have rarely focused on demand side interventions [33]. A recent example of a policy targeting demand by utilizing green public procurement is the 2018 EGalim food law in France. It requires that $50 \%$ of products offered by mass public catering companies to school canteens be sustainable (including 20\% organic products) by 2022 [34]. The EU follows six public procurement strategic priorities, one of which is the increase of innovative, green and social procurement.

Many participants discussed food labels (ecolabels and certification schemes) as a way to increase the sustainability of FVCs by signaling to consumers the added value of these products and thus justifying their higher prices.

There was this article in the paper some 2-3 years ago with the title 'cheap food is an expensive deception' and that is exactly what it is; an expensive deception. (P12-IS)

We are not confident that consumers can fully appreciate and understand information on value chain price distribution. (P26-IT)

Interviewees were concerned about food fraud and false labelling, and how these may hinder the transition to more sustainable food systems. The examples of selling haddock as cod and horse meat as beef were mentioned by some, as well as the lack of consistency in origin labels despite the EU directive mandating the specification of the country of origin. In addition, interviewees identified as problematic the large number of different labels and certifications available in the market, because of their capacity to confuse consumers.

There are so many different labels, instead of having one label where you'd know yes this here is PLA [bioplastic material] and you can distinguish it from the [plastic materials]. [... ] So, you know, a more integrated approach [to labels]. (P8-IS)

Despite these issues, labels and various environmental and health certification schemes were thought to be increasing in prevalence, mirroring consumers' concerns regarding the impact of food systems. Concerning organic production, for example, one participant highlighted that organic products are gaining scale and becoming 'mainstream' for large grocery retailers:

Large-scale retailers have started to produce their own organic brands (private labels), which means that there is an ever-increasing and real interest of the food distribution system in organic products.

(P26-IT) 
Views were, however, mixed in terms of the appropriate governance of labels, with some participants proposing public-led schemes, and others highlighting the importance of private governance schemes. Those in support of more public sector oversight argued for the need to counter greenwashing attempts by mandating harmonized quality standards throughout the value chain.

\subsection{Increase Transparency and Education on FVCs and Invest in Food Innovation}

Various knowledge-related tools were proposed by interviewees (see Table 3).

Table 3. Knowledge-related policy tools identified as solutions by interviewees.

\begin{tabular}{cc}
\hline Policy Tools & Proposed Solutions by Stakeholders \\
\hline \multirow{3}{*}{ Knowledge-related tools } & $\begin{array}{c}\text { Consumer education regarding food supply chains (IS, IT, UK, EU) } \\
\text { Increase transparency (through e.g., traceability) (FR, IT, IS, EU) } \\
\text { Invest in food R\&D (FR, IS, IT) }\end{array}$ \\
\cline { 2 - 2 } & $\begin{array}{c}\text { Less Commonly Identified } \\
\text { Training of culinary professionals (e.g., Chefs) to incorporate sustainability } \\
\text { concerns (IS, EU) }\end{array}$ \\
Behavioural interventions (e.g., nudging) (EU) \\
Social marketing (connect health to sustainability) (IT, EU) \\
Improve science communication about nutrition, health and sustainability (IS)
\end{tabular}

Most commonly discussed was the importance of educating consumers about the environmental and social impacts of food production.

People want to reconnect with their food (apples grow on trees), to understand where their food comes from. They want to recognize the products they eat. (P24-FR)

The perspectives of academic researchers and consultants' diverged somewhat from those of other stakeholders, in that the former argued for more evidence-based policies to influence consumer behaviour. As such, they emphasized the importance of developing sustainable food consumption policies based on behavioural insights, as a way to produce evidence based-rather than assumption based-policies. Experience in this regard was drawn from food waste reduction strategies (P30-EU), insights from health behaviour change (P11-IS), the effects of advertising on consumption (P2-IS), and the effects of nutrient-based labelling (P11-IS, P38-FR).

Several interviewees discussed the need for transparency to foster accountability in FVCs and communicate with consumers more directly:

Everything that unveils [this process] and shows how it really is [is a positive development] because people are not stupid and they want to know. But the industry has sort of [...] thrown a veil over it and [the product] just arrives ready at the store for you.

(P15-IS)

As a manufacturer, you must pay attention to the increasing demands for traceability of ingredients and food safety, and ensure a very strong sustainable supply chain. (P21-UK)

Various technologies were mentioned in the context of increasing the transparency of FVCs: most commonly blockchains and QR codes. Interviewees highlighted the importance of informing consumers about FVCs in terms of both gaining a market advantage-e.g., by highlighting the origin of products (P32-FR) - as well as fostering more realistic consumer expectations about various food characteristics, such as freshness and the role of technology in extending product life (P15-IS).

Many participants argued that solution pathways require the fostering of stronger communication between producers and consumers, with the potential for increasing the resilience of food value chains: 
Today, direct feedback and the ability to speak with customers immediately is an important part of the information chain. This increases the reaction pressure on the manufacturing companies. (P21-UK)

Retail stakeholders observed that, in recent years, consumers have already taken on a more active role in driving change in the food system (P32-FR, P34-FR, P37-FR). Millennials were thought to be especially resourceful, proactive and militant, applying pressure on companies through their use of social media and consumer screening apps (P34-FR).

Some stakeholders mentioned increased investment in food R\&D as being important for improving productivity and for adding value-added at all of the stages of the FVC. Food R\&D discussions ranged from innovations in agriculture that can improve farming output and quality (P35-FR) to more direct distribution to consumers and online retailing (P27-IT, P5-IS), and the potential for food packaging innovations which are less harmful to the environment (P6-IS).

\subsection{Promote Multi-Stakeholder Approaches and Address Power Asymmetries}

Many interviewees discussed the role, distribution of responsibilities and power of different actors in the governance of food systems, with particular attention being given to large retailers and civil society's influence (see Table 4).

Table 4. Possible solutions identified by stakeholders classified as governance policy tools.

\begin{tabular}{cc}
\hline Policy Tools & Proposed Solutions by Stakeholders \\
\hline Leverage the power of large retailers (FR, IS, IT, UK) \\
Civil society's role in governance (FR, IS, EU) \\
Less Commonly Identified \\
\cline { 2 - 2 } Governance tools $\quad$ Cooperative models (IT, EU) \\
Public-Private Partnerships (PPPs) for sustainable solutions (IS, UK) \\
Pay attention to cultural differences when formulating food policy (UK, EU) \\
FVC actors' collaboration on sustainability initiatives/break silos (EU) \\
Food policy councils to improve stakeholder engagement and participation (EU) \\
Enable degrowth and post-growth policies (EU) \\
Integrate food policy considerations with urban planning (FR) \\
Strengthen consumers' association with political and financial support (IS) \\
Advance a cross-sectoral approach to food policy (IS) \\
Academia's role as an independent facilitator among different FVC actors (IT) \\
Strengthen public participation (e.g., through citizen panels) (UK)
\end{tabular}

Interviewees believed that retailers have an important role to play in the transition to sustainability, in part due to their significant negotiating power in food systems.

Retailers often increase their sustainability commitment. Thus they often ask their suppliers to give a "present picture" of their sustainability agenda, and a short to medium-term forecast of the future for the sustainability management issues (such as plastic use in the products). Thus retailers can have a positive impact (and be part of the "solution") on the sustainability practices of the whole food system. (P23-IT)

Views were mixed, however, as some participants were concerned about power asymmetries in international FVCs, which sustain retailers' advantages over other FVC actors.

If you would map it out, most production companies in the world are under the ownership of just a few companies. [Just look at] how these companies have behaved in the past with regards to child slavery, how they treat their employees, their environmental policy and [yet] those are the companies that are most eager to sign pretty papers. (P4-IS) 
Some participants, however, expressed confidence in the ability of private companies to drive changes in FVCs, e.g., through voluntary agreements and initiatives (P37-FR). There were, however, mixed perspectives regarding the shift to plant-based diets and meat free alternative foods, with some regarding it as a niche market and others claiming that that it is a long-term and more substantial shift, reflecting rising sustainability concerns amongst European consumers. In this process, NGOs assumed responsibility for demonstrating expected future trends and pressuring companies toward a more proactive stance in the transition to more sustainable food systems (P40-FR). Yet other participants emphasized that these trends are often counteracted by other concurrent trends, pointing to cross-sectoral effects:

Bacon has never been as popular in Iceland; bacon sales increased so much that Iceland had to import pork bellies in order to meet the demand. So it's [both] this ketogenic [diet fad] and the tourism industry [... ] they all want bacon for breakfast. (P3-IS)

EU-level participants emphasized the need for multi-stakeholder forums where different FVC actors exchange knowledge and information in order to address sustainability issues from a food system perspective and break down silos.

We need to build food policy councils which frame the food policy in Europe in the national and local levels. This may help break the silos and bring all stakeholders together, including farmers, producers, retailers, employers, consumers, to talk and increase transparency in food systems in Europe. And this would also enable capturing cultural and local differences. (P29-EU)

Many participants highlighted the role of civil society in raising the awareness of environmental issues and pressuring the food sector (among other sectors) to address sustainability challenges. At the time of the interviews, the climate youth movement (spearheaded by Greta Thunberg) and the civil disobedience movement Extinction Rebellion (XR) had both been very vocal and visible in the media [35,36], and to some extent in the academic discourse [37,38]. It is thus unsurprising that this was high in the consciousness of the participants.

The biggest icon in the world today is a 16-year-old girl which is amazing. And the scared old men do all they can to bring her down. And all she is saying is 'read and listen to the scientists'. (P13-IS)

Social movements affect industry indirectly through their influence on public policy, often by shifting public debates to incorporate new and presently marginalised perspectives [39]. As an Icelandic producer argued:

[Radical discourse] pushes the cart in the right direction. (P16-IS)

The role of NGOs in food system governance has also become more prominent in recent decades, though it takes diverse forms often relying on collaboration [40]. As a participant from an international NGO argued:

Generally speaking, agricultural supply chains adopt a passive posture with regard to changes in consumer behaviour, meaning that they tell themselves that they will adapt once demand has changed. But at the same time, there are things to anticipate because we can't adapt food production overnight [...]. Our goal is to get them to be more proactive about changes by showing that the demand is already there. (P40-FR)

\subsection{Local-Level Solutions Supporting Seasonal and Regional Products and a Circular Economy Framework}

The most commonly identified solutions that emerged were ones that can be classified as strategic tools (see Table 5). 
Table 5. Possible solutions identified by stakeholders classified as strategic policy tools.

\begin{tabular}{cc}
\hline Policy Tools & Proposed Solutions by Stakeholders \\
\hline Support seasonal production (FR, IS, UK, EU) \\
Support regional/local production (FR, UK, EU) \\
Emphasize local-level solutions (IT, UK, EU) \\
Implement circular economy policies (FR, IS, IT) \\
Reduce animal production (FR, IS, UK) \\
\cline { 2 - 2 } Less Commonly Identified \\
\cline { 2 - 2 } \\
Prategic tools \\
Provide clear quality guidelines (IS, UK) \\
Align national/regional policy with global issues (FR) \\
Utilize a system-perspective on food production (IS) \\
Governments must agree on common international sustainability goals (UK) \\
\hline
\end{tabular}

Some participants emphasized the importance of seasonal products in achieving sustainable food production (P18-IS, P19-UK, P29-EU, P32-FR, P38-FR, P40-FR). They argued for the importance of shortening FVCs by initiatives such as buying straight from farms and effectively dispensing with intermediaries. This could increase farmers' margins and reduce food waste.

Many participants, however, shared a critical view regarding trends such as the consumption of locally produced vegetables, and their appraisal of the slow food movement was by and large unfavourable. They argued that such trends still do not achieve a high market share and face numerous challenges in terms of mainstreaming and up-scaling:

We see a growing awareness of regional and national product demands as well as the trend towards old types of fruits and vegetables. But it is a very slow and small movement that is fighting its way up the social media. If I look at the supermarkets, then the shelf meters have moved rather to convenient food and serve the growing amount of single households. (P20-UK)

For the food industry at large, the local consumption and production of fruits and vegetables is still a marginal activity serving a relatively small segment of consumers:

People who value freshness are entering the weekly farmer's market, which is increasingly enjoying new popularity. But, [ ... ] it is a very, very small part of the entire population. Thus, these people are irrelevant for the majority of the food industry. (P20-UK)

Such a divide between the mainstream production and consumption of food raised concerns, as a closer relationship between both sides was considered by some to be a key element in achieving resilience:

The closer the relationship between producer and consumer, the stronger and more resilient the whole food chain. (P24-IT)

Concerning organic production, one interviewee highlighted that organic products are gaining scale and becoming part of the marketing strategy of large European retailers. It is unclear, however, how far the organic sector will develop (P26-IT).

When discussing the challenges and barriers towards more sustainable fresh food consumption (such as fruits and vegetables), participants highlighted the structural nature of the problem, in which the market is characterised by farms and manufacturers that are mostly targeting the mass market, which is very price conscious:

It is a structural problem, as most farms and manufacturers are conventional producing companies. The conversion would cost a lot of time and money, and we would not have guarantees that the market or the customers will pay for it. (P20-UK) 
Another participant pointed out that the discourse on imported versus locally produced food is usually not based on systems thinking regarding the different stages of production, e.g., sourcing the inputs:

There is chicken and chicken. Danish chicken is not in the local environment. But what is more local: to import the chicken or to buy the chicken feed (because that's imported)? [ ... ] You need $2 \mathrm{~kg}$ of feed to produce $1 \mathrm{~kg}$ of meat. Which is more environmentally-friendly? Clearly the imported meat because the feed for that chicken is close to the chicken factory. (P4-IS)

A fundamental question relates to how FVCs address current and future challenges by increasing resilience. Tendall et al. [41] definition of resilience in the context of food systems, as "the capacity over time of a food system and its units at multiple levels, to provide sufficient, appropriate and accessible food to all, in the face of various and even unforeseen disturbances" (p.19), also reflects the perspective of those stakeholders who discussed resilience in these interviews. The prioritization of key policy-making decisions about sustainability in food value chains would need to be based on a shared vision for the future and a common awareness of the relevant time scales, as one participant put it:

Are we looking at the [... ] chain that is ... just now - our lifespan - or are we looking at the value chain in terms of the future? And which is more important? Is the world ending? Is it not ending? And where are we at in this picture? And which are our interests? (P10-IS)

Another participant noted that the focus on the future of agriculture was already visible in the global retail industry:

What is most noticeable now [in food product exhibitions] is the focus on the future [...] and [there is awareness that] when considering current agricultural practices there will not be enough land, water etc. to continue on the same path. (P18-IS)

Interviewees frequently discussed the circular economy framework as a strategic direction for integrating environmental sustainability goals in agri-food systems. Many argued that the framework was important for advancing concrete solutions to sustainability issues in food systems.

Food loss (i.e., the loss of agricultural produce due to damage) and food waste (i.e., the throwing away of food still fit for consumption) [42] were discussed by several interviewees. As the CEO of a wholesale firm in Iceland emphasized, food loss should be addressed as a systemic problem at all stages of the value chain:

Food loss is a "hot potato" nobody wants to own it but it is present. [ ... ]. In order to succeed in this then someone has to own it. It is best that the one who has it on their table should also be the one who owns it. You don't tidy up your own garden by throwing everything over to your neighbours' just because he is taking the garbage anyway. (P4-IS)

Another of the proposed solutions that emerged from the interviews was the need to reduce meat consumption. Interviewees identified increased consumer demand for alternative plant-based products in three countries, but many highlighted the need for policy to support a transition to more sustainable agri-food systems, e.g., by reducing subsidies to the meat industry (P6-IS). New challenges were also identified in the case of dairy companies attempting to meet the demand for plant-based alternatives by investing in and buying up companies that produce dairy substitutes. As the products these alternatives are derived from are often sourced from abroad (e.g., cashews, almonds, etc.) this raises new and different challenges for the structure of supply chains (P34-FR). 


\section{Discussion and Recommendations}

The findings indicate that there is widespread recognition among different stakeholder groups across different national contexts of the challenges that are faced by contemporary agri-food systems. There is also consensus regarding the need to transform agri-food systems to increase their sustainability and resilience. Where perspectives differ, however, is on how this transition can be achieved such that it is as smooth and as fair as possible for all of the relevant parties, including consumers and FVC actors. Interviewees also voiced concerns regarding food systems' abilities to support future generations amidst numerous challenges. In this study, we used a typology of policy tools [31] to structure these findings and highlight the commonalities across different stakeholder groups in different countries in order to derive recommendations drawing from these diverse perspectives. The following discussion addresses some of the main themes and topics that emerged from the interviews.

Many of the proposed regulatory instruments mentioned by the interviewees are already incorporated in the EU's Farm to Fork Strategy: the EU's plan for transitioning towards fairer, healthier and more environmentally-friendly food systems in the EU. The strategy comprises one the 11 components of the EU Green Deal, the ambitious aim of which is to make Europe the first climate-neutral continent by 2050 [43]. The successful implementation of this strategic framework will, however, also depend on aligning the Common Agricultural Policy (CAP) with the sustainability objectives of the EU Green Deal [7] and the SDGs [44]. Addressing soil erosion was the most commonly mentioned environmental issue in need of direct regulatory intervention. There is a wealth of research to support the effect of the excessive use of fertilizers and pesticides on soils, which is reflected also in the soil protection measures that are being introduced in various European countries in the absence of a common EU directive for soil protection [45].

Emphasis was also placed on voluntary and cooperative governance solutions, which reflects the increased engagement of private actors in the governance of food supply chains [46]. FVCs have become increasingly globalised in the last few decades, leading to more complex food governance. Globalization has led to the fragmented territorial jurisdiction of value chains and the increased participation of international and regional organizations in governance [47].

The topic of governance is also relevant to the discussion of private versus state-run labelling/certification schemes. The literature indicates that the support for private labels often rests on the need for the innovation and flexibility that can arise from less rigid standards [48]. However, the large number of available eco-labels (by one estimation, over 450 [49]) has often been identified as a challenge both in our interviews and in the academic literature [50]. The differences between interviewees regarding the role and governance of labels in part reflects the varying stances regarding consumers' 'right to know' versus 'need to know' about food production processes [51]. Diverse perspectives also exist in academic debates on the efficacy [52,53] and legitimacy [54] of labels and certification schemes as management tools.

Differing perspectives aside, studies show that consumer trust in eco-labels tends to increase with the use of third-party accreditation [55], which can also circumvent the pubic-private divide. In terms of achieving environmental sustainability goals, the emerging scientific consensus is that these schemes in and of themselves "cannot drive transformation of production practices toward greater environmental sustainability" [56] (p. 431). "Whatever the outcomes of labelling and certification schemes, their emergence owes to the lack of regulatory oversight; their existence is, thus, necessary in dealing with regulatory gaps" [57].

Certification schemes and labels are one response to the identified demand for transparency. It was deemed important by the stakeholders in this study to find concrete ways to counter consumers' growing scepticism regarding technological advancements in food production, which is evident in the recent proliferation of 'free-from' food labels [51]. Other solutions to create more transparent FVCs which were discussed were digital technologies such as the use of QR codes and blockchains. These technologies appear promising in their ability to provide objective, real time data about increasingly global FVCs to consumers and other stakeholders, reducing risks for FVC actors and increasing 
regulatory compliance. However, a number of challenges remain, e.g., complications for tracing at the production stage, gaining consumer acceptance [58], and the possibility of exacerbating power asymmetries between FVC actors (especially smallholders) [59].

Many stakeholders in this study emphasized the importance of both technological advancements and food innovation to bringing about sustainable transitions for agri-food systems. Recent research indicates that public investment in food $R \& D$ in wealthy countries has been steadily dropping in the last few decades, and although private investment has increased, both types are necessary in order to address agri-food system challenges [60]. Research also indicates that more integrated chains and government structures that enable collaborative relationships between actors are important for fostering more environmentally-friendly innovation [61]. Innovation has an important role to play in the transition to more sustainable food systems, requiring appropriate incentives, regulations and social licence [62].

Cross-sectoral effects were discussed less frequently, but are an important consideration, particularly for policy-makers. An example, which arose from this study, was the unprecedented growth of the Icelandic tourism industry, which was very impactful in terms of food demand and food policy-making in Iceland. Cross-sectoral effects (and ensuing policy failures) highlight the need to take account of these effects when designing sustainable food policies [63]. From a wider perspective, it is also imperative to consider trade-offs and synergies relating to the water-energy-food nexus $[4,64]$, e.g., the effect of biofuel production on food security [65]. Previous research has identified food policy silos, which can prevent an appropriate response to issues that transcend specific sectors [64]. The Sustainable Development Goals' wide scope also requires the integration of policies heretofore constrained by silos [66], which can also ameliorate trade-offs from cross-sectoral effects.

Another topic generating much discussion was the importance of local and seasonal production to sustainability. However, there was no clear consensus on what precisely constitutes local and seasonal production. The terms 'local' and 'seasonal' have no clear, commonly agreed-upon definition which obscures the discourse $[67,68]$. Seasonality can be interpreted in two distinct ways: from a global perspective (i.e., a natural production season consumed elsewhere in the world) and from a local perspective (i.e., a natural production season consumed within the same climatic region) [68]. Territoriality has been proposed as a concept to address the need for more locally-focused (bottom-up) versus national/regional-level (top-down) approaches which take into account the specific requirements of rural versus urban areas [69-71].

Whether seasonal and local products can deliver sustainability benefits in contrast to global value chains is an important research question. The evidence to date indicates that local and short value chains can deliver economic and social benefits to producers, but some local systems of production may generate greater carbon emissions than conventional supply chains due to relatively fragmented distribution which is reliant on a mass of small-scale movements [72]. However, distinguishing local from global FVCs is often very complicated, as, in practice, few FVCs are purely local or purely global. The answer is, thus, complex and far from unequivocal, pointing to the need for a less divisive discourse and an increased focus on identifying trade-offs and synergies among local and global food chains $[67,73]$.

The growing scientific consensus that shifting consumption to a more plant-based diet should be a major component of effective strategies toward healthier and more sustainable agri-food systems $[3,74]$ was also reflected in this study's interviews. However, substantial reductions in meat consumption, by at least $50 \%$ globally in order to keep within environmental limits [3], face public resistance due to various cultural, personal and social values associated with meat consumption [75,76]. Interviewees mentioned various meat alternatives as viable ways to promote meat reduction in more reticent consumer segments. Research indicates, however, that the sustainability gains of meat alternatives may not be as extensive as implied in the discourse, due to the high level of processing that they typically require [77]. 
Finally, a topic that emerged from the interviews was the importance of new business models, with a circular economy model for agri-food systems being the most discussed. Although widely used, circular economy as a term lacks a single, agreed-upon definition $[78,79]$, but has, nonetheless, achieved widespread uptake by policy-makers and the business community alike [80]. This is evident from our interviews since the concept was discussed by a wide array of stakeholders, from FVC actors to NGOs and policy-makers. The following definition by Jurgilevich et al. [81] is most appropriate here, as it encompasses most of the issues that emerged from the interviews when discussing circular economy policies in the context of agri-food systems:

Circular economy regarding the food system implies reducing the amount of waste generated in the food system, re-use of food, utilization of by-products and food waste, nutrient recycling, and changes in diet toward more diverse and more efficient food patterns (p. 2).

Some authors identify challenges for the concept in achieving environmental sustainability due to the lack of rigorous scientific research underpinning environmental impacts [80]. One solution would be to utilise precise measurements for material flows, which would ensure that environmental aspects are accounted for (e.g., recycling rates provide no information on actual reductions in resource use) [78]. Effective policy-making should also address food loss and waste along the entire food supply chain, with an emphasis placed on developing and supporting closed-loop value chains [74]. Waste (including food waste) is one of the priority areas of the EU Circular Economy Action Plan [82], which in turn is part of the European Green Deal [83].

It should be noted that since these interviews were conducted, the UK has left the European Union, and as of 31 January 2020 is no longer an EU member (though partnership negotiations are ongoing) [84]. The Brexit debate has heightened concerns about EU cohesion, which could have wider implications for European food systems in the future [85]. The current pandemic has also thrown into sharp relief many of the concerns about EU cohesion and integration [86], though the implications are yet to be fully understood as the pandemic is still underway [87].

Finally, drawing from these stakeholder-based insights, the following recommendations were formulated from an agri-food system perspective to include all of the relevant actors and target recommendations accordingly (see Table 6.) 
Table 6. Policy recommendations targeted to different stakeholder groups in support of sustainable food consumption, derived from findings.

\begin{tabular}{|c|c|c|c|c|}
\hline \multirow{2}{*}{ Policy Tool } & \multirow{2}{*}{ Policy Topic } & \multicolumn{3}{|c|}{ Stakeholder Group } \\
\hline & & Government & FVC Actors & Civil Society \\
\hline $\begin{array}{l}\text { Direct } \\
\text { activity } \\
\text { regulation }\end{array}$ & Policy integration & $\begin{array}{l}\text { Integrate health and nutrition goals with } \\
\text { sustainability goals; Address policy contradictions } \\
\text { with sustainability goals and integrate agri-food } \\
\text { policies with environmental sustainability targets } \\
\text { (e.g., climate neutrality); Formulate policies that } \\
\text { capitalize on cross-sectoral synergies }\end{array}$ & $\begin{array}{l}\text { Device strategies that promote long-term perspectives } \\
\text { in food production and consumption; } \\
\text { Support a shift of production to more sustainable } \\
\text { patterns (e.g., reduce meat production) }\end{array}$ & $\begin{array}{c}\text { Identify policy gaps and inconsistencies to more } \\
\text { effectively achieve policy integration for sustainability; } \\
\text { Advocate systemic solutions alongside } \\
\text { changing lifestyles }\end{array}$ \\
\hline $\begin{array}{l}\text { Market-based } \\
\text { tools }\end{array}$ & Market incentives & $\begin{array}{l}\text { Formulate labelling/certification policy based on } \\
\text { evidence of the limitations of private sector } \\
\text { voluntary initiatives; Monitor compliance and } \\
\text { effectiveness of labels in achieving sustainability } \\
\text { goals; Align public procurement policies with } \\
\text { sustainability objectives }\end{array}$ & $\begin{array}{l}\text { In the absence of a mandatory label, use only } \\
\text { well-established and reputable third-party accredited } \\
\text { labelling schemes; Avoid greenwashing }\end{array}$ & Inform consumers about reputable labelling schemes \\
\hline \multirow[t]{2}{*}{$\begin{array}{l}\text { Knowledge- } \\
\text { related tools }\end{array}$} & $\begin{array}{l}\text { Transparency and } \\
\text { education }\end{array}$ & $\begin{array}{l}\text { True cost pricing including social costs; Food } \\
\text { education in schools; Utilize behavioural insights; } \\
\text { Transparency about policy trade-offs; Shape the } \\
\text { food environment to promote sustainable diets } \\
\text { and support private sector initiatives to this effect }\end{array}$ & $\begin{array}{c}\text { Release annual sustainability reports with appropriate } \\
\text { metrics that take planetary boundaries into account; } \\
\text { Adopt technologies that increase the transparency of } \\
\text { FVCs; Shape the food environment to promote } \\
\text { sustainable diets }\end{array}$ & $\begin{array}{c}\text { Increase consumer literacy on complexity of food } \\
\text { consumption; } \\
\text { Educate on the sustainability and health gains of } \\
\text { sustainable diets }\end{array}$ \\
\hline & Food innovation & $\begin{array}{l}\text { Invest in food innovation that advances } \\
\text { sustainability goals; Develop frameworks for } \\
\text { assessing innovation based on sustainability } \\
\text { criteria and metrics }\end{array}$ & $\begin{array}{l}\text { Invest in food innovation that advances } \\
\text { sustainability goals }\end{array}$ & $\begin{array}{l}\text { Monitor and educate about the effectiveness of specific } \\
\text { food innovations on sustainability goals }\end{array}$ \\
\hline $\begin{array}{l}\text { Governance } \\
\text { tools }\end{array}$ & $\begin{array}{l}\text { Power asymmetries } \\
\text { and influence }\end{array}$ & $\begin{array}{l}\text { Target policies towards FVC actors with the power } \\
\text { to change the system; Support consumer groups; } \\
\text { Identify and engage broad scope of stakeholders }\end{array}$ & $\begin{array}{l}\text { Recognize the role and power each FVC actor has to } \\
\text { transform the food system; Participate in } \\
\text { multistakeholder initiatives and form strategic } \\
\text { alliances with stakeholders to pursue common goals }\end{array}$ & $\begin{array}{l}\text { Target pressure on FVC actors and governmental } \\
\text { bodies with the most power to implement } \\
\text { transformative policies; Educate about the limited role } \\
\text { of consumers and the need for systemic change }\end{array}$ \\
\hline \multirow{2}{*}{$\begin{array}{l}\text { Strategic } \\
\text { tools }\end{array}$} & $\begin{array}{l}\text { Local vs. global } \\
\text { FVCs }\end{array}$ & $\begin{array}{l}\text { Formulate policies that override false dichotomies } \\
\text { among local and global FVCs }\end{array}$ & $\begin{array}{c}\text { Identify and address trade-offs and synergies in } \\
\text { FVC logistics }\end{array}$ & Promote policies that optimize sustainability outcomes \\
\hline & $\begin{array}{l}\text { New business } \\
\text { models: circular } \\
\text { economy }\end{array}$ & $\begin{array}{l}\text { Monitor environmental performance with } \\
\text { appropriate indicators and frameworks }\end{array}$ & $\begin{array}{c}\text { Monitor environmental performance with appropriate } \\
\text { indicators and frameworks }\end{array}$ & $\begin{array}{l}\text { Scrutinize circular economy policies and evaluate } \\
\text { them on the basis of sustainability outcomes; Inform } \\
\text { consumers about the effectiveness of specific circular } \\
\text { economy policies }\end{array}$ \\
\hline
\end{tabular}




\section{Conclusions}

This study elicited the perspectives of stakeholders of agri-food systems in four different European countries, analysing the most commonly identified and cross-cutting solutions for transitioning to more sustainable food production and consumption. The most commonly proposed solutions can be classified as strategic tools, reflecting a shared recognition of the need for policy cohesion in the service of long-term goals. This finding mirrors the emphasis in the academic literature on addressing food as a systemic cross-cutting issue which demands the determination of common goals and the coordination and collaboration of many different governance actors [88]. A mix of policy instruments capitalizing on synergies [74] while recognizing trade-offs [89] is more conducive to effectively addressing pressing challenges due to the complexity of agri-food systems and their multiple interactions with other systems [90].

The topics and possible solutions discussed during the in-depth interviews with stakeholders reflect their concerns and perspectives at the time of the data collection. Although the study was conducted before the recent Covid-19 pandemic [91], it remains relevant. Besides the obvious and inescapable connections to be made between the ecological health of ecosystems and human health [92], many of the recommendations which were geared towards increasing the sustainability of agri-food systems would also contribute to their resilience to future challenges.

Nonetheless, some pertinent issues which the literature regards as important to consider as we attempt to transition to more sustainable food systems did not emerge from our interviews. One important aspect that received little attention, despite its evident influence on policy-making, is the effect of binding international trade agreements and how these interact with both regional and national policy. Policy for the public interest (as all sustainability policies are by definition) may be hindered by trade-policy goals, necessitating the consideration of these interactions when regulatory frameworks are reformed to address sustainability challenges [93]. Another topic which received little discussion was the effect of EU competition law on collaborative practices. Previous stakeholder-based research indicates that competition law can be a substantive barrier to collaborative sustainability initiatives [94]. Furthermore, nutrition and the importance of healthy diets was discussed very little in our interviews, and the discussion also lacked the crucial connection to poverty measures and the effects of food insecurity [95] which the current pandemic has further exposed [96]. Access to healthy diets is an important issue for cash-strained households which resort to less healthy but cheaper convenience food products, thus exacerbating environmental and health issues [95]. Future research should also address and analyse the global impact of European food systems. Although this study did not explicitly address the global dimension of European food systems, sustainability goals necessitate a global perspective [95]. Finally, differences in national contexts require a more in-depth investigation, since several topics which emerged from our study were more context-specific. Nonetheless, identifying common ground in proposed solutions is important within the context of European policy-making.

Author Contributions: Conceptualization, N.M.S., G.O., S.G.B.; methodology, N.M.S., G.O., M.N., C.F., A.S., P.-M.A., M.G.; formal analysis, N.M.S.; investigation, N.M.S., H.S., M.N., D.v.B., A.S., M.D.P., L.B., E.H.; data curation, N.M.S., G.O., M.N., A.S.; writing—original draft preparation, N.M.S.; writing—review and editing, N.M.S., G.O., M.G., A.S., M.N., D.v.B., E.H.; supervision, G.O.; project administration M.N., C.F.; funding acquisition, S.G.B. All authors have read and agreed to the published version of the manuscript.

Funding: The VALUMICS project “Understanding Food Value Chain and Network Dynamics” received funding from the European Union's Horizon 2020 research and innovation programme, under grant agreement No. 727243. https://valumics.eu/.

Acknowledgments: The authors would like to thank the interviewees for their participation in this study, and the two anonymous reviewers for providing useful comments.

Conflicts of Interest: The authors declare no conflict of interest. The funders had no role in the design of the study; in the collection, analyses, or interpretation of data; in the writing of the manuscript, or in the decision to publish the results. This report reflects only the authors' view, and the EU Funding Agency is not responsible for any use that may be made of the information it contains. 


\section{Appendix A}

Table A1. Stakeholders' descriptives (the type of organization and the stakeholder's role in it), and pseudonyms with country codes.

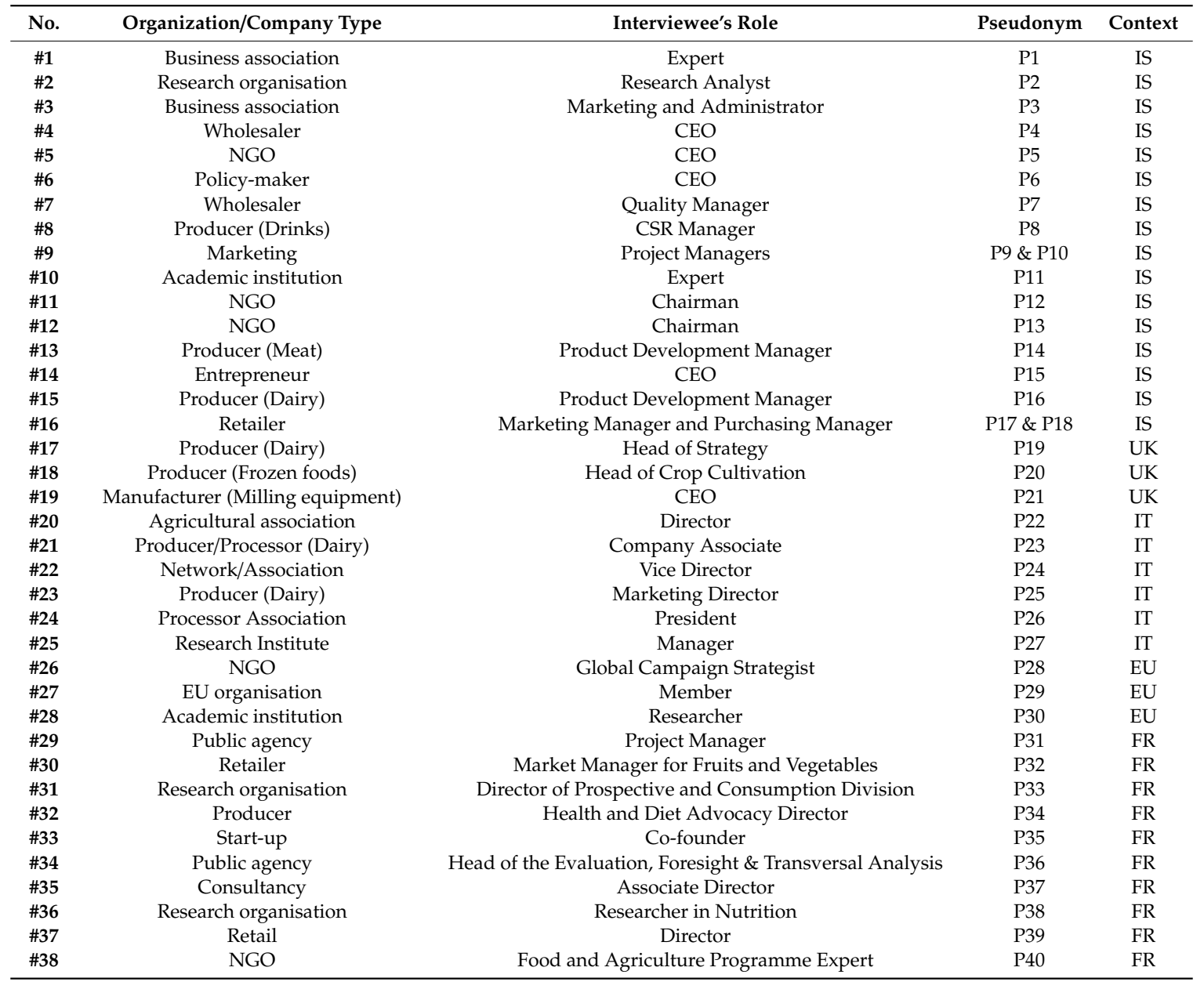

\section{References}

1. FAO (Food and Agriculture Organization of the United Nations). The State of Food and Agriculture: Climate Change, Agriculture, and Food Security; FAO: Rome, Italy, 2016; Available online: http://www.fao.org/3/ai6030e.pdf (accessed on 16 February 2020).

2. Gordon, L.J.; Bignet, V.; Crona, B.; Henriksson, P.J.G.; Van Holt, T.; Jonell, M.; Lindahl, T.; Troell, M.; Barthel, S.; Deutsch, L.; et al. Rewiring food systems to enhance human health and biosphere stewardship. Environ. Res. Lett. 2017, 12, 100201. [CrossRef]

3. Willett, W.; Rockström, J.; Loken, B.; Springmann, M.; Lang, T.; Vermeulen, S.; Garnett, T.; Tilman, D.; Declerck, F.; Wood, A.; et al. Food in the Anthropocene: The EAT-Lancet Commission on healthy diets from sustainable food systems. Lancet 2019, 393, 447-492. [CrossRef]

4. $\quad$ EEA (European Environment Agency). Food in a Green Light: A Systems Approach to Sustainable Food. 2017. Available online: https://www.eea.europa.eu/publications/food-in-a-green-light (accessed on 3 March 2020).

5. FAO. Transforming Food and Agriculture to Achieve the SDGs: 20 Interconnected Actions to Guide Decision-Makers; FAO: Rome, Italy, 2018; Available online: http://www.fao.org/3/19900EN/i9900en.pdf (accessed on 16 February 2020). 
6. Nellemann, C.; MacDevette, M.; Manders, T.; Eickhout, B.; Svihus, B.; Prins, A.G.; Kaltenborn, B. The Environmental Food Crisis-The Environment's Role in Averting Future Food Crises. A Unep Rapid Response Assessment; United Nations Environment Programme: Birkeland Trykkeri, Norway, 2009; ISBN 978-82-7701-054-0.

7. Galli, F.; Prosperi, P.; Favilli, E.; D'Amico, S.; Bartolini, F.; Brunori, G. How can policy processes remove barriers to sustainable food systems in Europe? Contributing to a policy framework for agri-food transitions. Food Policy 2020, 101871. [CrossRef]

8. FAO. Sustainable Food Systems: Concept and Framework. 2018. Available online: http://www.fao.org/3/ ca2079en/CA2079EN.pdf (accessed on 19 February 2020).

9. Ruben, R.; Verhagen, A.; Plaisier, C. The Challenge of Food Systems Research: What Difference Does It Make? Sustainability 2018, 11, 171. [CrossRef]

10. Lorek, S.; Spangenberg, J.H. Sustainable consumption within a sustainable economy-Beyond green growth and green economies. J. Clean. Prod. 2014, 63, 33-44. [CrossRef]

11. Lorek, S.; Fuchs, D. Strong sustainable consumption governance-Precondition for a degrowth path? J. Clean. Prod. 2013, 38, 36-43. [CrossRef]

12. UN [United Nations]. Goal 12: Ensure Sustainable Consumption and Production Patterns: Facts and Figures. Available online: https://www.un.org/sustainabledevelopment/sustainable-consumption-production/ (accessed on 20 May 2020).

13. Stockholm Resilience Centre. How Food Connects all the SDGs: Johan Rockström and Pavan Sukhdev Present New Way of Viewing the Sustainable Development Goals and How They Are All Linked to Food. 2016. Available online: https://www.stockholmresilience.org/research/research-news/2016-06-14-how-foodconnects-all-the-sdgs.html (accessed on 27 May 2020).

14. UNEP. Food Systems and Natural Resources: A Report of the Working Group on Food Systems of the International Resource Panel; Job Number: DTI/1982/PA; Westhoek, H., Ingram, J., Van Berkum, S., Özay, L., Hajer, M., Eds.; United Nations Publications: New York, NY, USA, 2016; ISBN 978-92-807-3560-4.

15. Akenji, L. Consumer scapegoatism and limits to green consumerism. J. Clean. Prod. 2014, 63, 13-23. [CrossRef]

16. COM. Towards a Sustainable Food System: Group of Chief Scientific Advisors. 2020. Available online: https://ec.europa.eu/info/sites/info/files/research_and_innovation/groups/sam/scientific_opinion_ -_sustainable_food_system_march_2020.pdf (accessed on 19 April 2020).

17. Lang, T.; Heasman, M. Food Wars: The Global Battle for Minds, Mouths, and Markets; Earthscan Publications Ltd.: London, UK, 2005; ISBN 978-1-85383-702-9.

18. Carter, R.; Ferdinand, T.; Chan, C. Transforming Agriculture for Climate Resilience: A Framework for Systemic Change; WRI: Washington, DC, USA, 2018; Available online: https://wriorg.s3.amazonaws.com/ s3fs-public/transforming-agriculture-climateresilience-framework-systemic-change_0.pdf (accessed on 24 February 2020).

19. UNEP. Sustainable Food Systems (SFS) Programme Document. 2017. Available online: http://www. scpclearinghouse.org/sites/default/files/10yfp-sfs-programmedoc.pdf (accessed on 25 March 2020).

20. Loorbach, D.; Frantzeskaki, N.; Avelino, F. Sustainability Transitions Research: Transforming Science and Practice for Societal Change. Annu. Rev. Environ. Resour. 2017, 42, 599-626. [CrossRef]

21. Markard, J.; Raven, R.; Truffer, B. Sustainability transitions: An emerging field of research and its prospects. Res. Policy 2012, 41, 955-967. [CrossRef]

22. El Bilali, H. Research on agro-food sustainability transitions: A systematic review of research themes and an analysis of research gaps. J. Clean. Prod. 2019, 221, 353-364. [CrossRef]

23. Pitt, H.; Jones, M. Scaling up and out as a Pathway for Food System Transitions. Sustainability 2016, 8, 1025. [CrossRef]

24. Luederitz, C.; Abson, D.J.; Audet, R.; Lang, D.J. Many pathways toward sustainability: Not conflict but co-learning between transition narratives. Sustain. Sci. 2016, 12, 393-407. [CrossRef]

25. Avelino, F.; Wittmayer, J.M. Shifting Power Relations in Sustainability Transitions: A Multi-actor Perspective. J. Environ. Policy Plan. 2015, 18, 628-649. [CrossRef]

26. Del Brío, J.Á.; Junquera, B. A review of the literature on environmental innovation management in SMEs: Implications for public policies. Technovation 2003, 23, 939-948. [CrossRef]

27. Brislin, R.W. Back-Translation for Cross-Cultural Research. J. Cross Cult. Psychol. 1970, 1, 185-216. [CrossRef] 
28. Directive (EU) 2016/680 of the European Union and of the Council of 27 April 2016, on the Protection of Natural Persons with Regard to the Processing of Personal Data. Available online: http://eur-lex.europa.eu/ legal-content/EN/TXT/PDF/?uri=CELEX:32016L0680\&from=EN (accessed on 24 February 2020).

29. Merriam, S.B.; Tisdell, E.J. Qualitative Research: A Guide to Design and Implementation; Jossey-Bass; Wiley: San Francisco, CA, USA, 2016; ISBN 978-1-119-00361-8.

30. Darbi, W.P.K.; Hall, C.M. Elite interviews: Critical practice and tourism. Curr. Issues Tour. 2014, 17, 832-848. [CrossRef]

31. Galli, F.; Favilli, E.; D'Amico, S.; Brunori, G. A Transition towards Sustainable Food Systems in Europe: Food Policy Blue Print Scoping Study; Laboratorio di Studi Rurali Sismondi: Pisa, Italy, 2018; ISBN 9788890896040.

32. Corbin, J.; Strauss, A. Basics of Qualitative Research: Techniques and Procedures for Developing Grounded Theory, 4th ed.; SAGE Publications: Los Angeles, CA, USA, 2015.

33. Hertwich, E. Life-cycle Approaches to Sustainable Consumption. Workshop Proceedings, 22 November IIASA Interim Report. 2002. Available online: http://pure.iiasa.ac.at/6714/ (accessed on 3 June 2020).

34. Government of France. LAW n ${ }^{\circ} 2018-938$ of 30 October 2018 for the Balance of Trade Relations in the Agricultural and Food Sector and Healthy, Sustainable and Accessible Food for All. 2018. Available online: https://www.legifrance.gouv.fr/affichTexte.do?cidTexte=JORFTEXT000037547946\&categorieLien=id (accessed on 24 June 2020).

35. Verhovek, S.H. Band of Nevada Ranchers Clash with Government on Cattle Grazing. New York Times. Available online: http://www.nytimes.com (accessed on 2 August 2001).

36. Taylor, M. Extinction Rebellion Plans New London Climate Crisis Shutdowns. The Guardian. 23 September 2019. Available online: https://www.theguardian.com/ (accessed on 4 May 2020).

37. Hagedorn, G.; Kalmus, P.; Mann, M.; Vicca, S.; Berge, J.V.D.; Van Ypersele, J.-P.; Bourg, D.; Rotmans, J.; Kaaronen, R.O.; Rahmstorf, S.; et al. Concerns of young protesters are justified. Science 2019, 364, 139-140. [CrossRef]

38. Slaven, M.; Heydon, J. Crisis, deliberation, and Extinction Rebellion. Crit. Stud. Secur. 2020, 8, 59-62. [CrossRef]

39. Schifeling, T.; Hoffman, A.J. Bill McKibben's Influence on U.S. Climate Change Discourse: Shifting Field-Level Debates Through Radical Flank Effects. Organ. Environ. 2017, 32, 213-233. [CrossRef]

40. Dauvergne, P.; Lister, J. Big brand sustainability: Governance prospects and environmental limits. Glob. Environ. Chang. 2012, 22, 36-45. [CrossRef]

41. Tendall, D.; Joerin, J.; Kopainsky, B.; Edwards, P.; Shreck, A.; Le, Q.; Kruetli, P.; Grant, M.; Six, J. Food system resilience: Defining the concept. Glob. Food Secur. 2015, 6, 17-23. [CrossRef]

42. Aschemann-Witzel, J. Waste not, want not, emit less. Science 2016, 352, 408-409. [CrossRef]

43. COM. Farm to Fork Strategy for a Fair, Healthy and Environmentally-Friendly Food System. 2020. Available online: https://ec.europa.eu/food/farm2fork_en (accessed on 25 May 2020).

44. Pe'Er, G.; Zinngrebe, Y.; Moreira, F.; Sirami, C.; Schindler, S.; Müller, R.; Bontzorlos, V.; Clough, D.; Bezák, P.; Bonn, A.; et al. A greener path for the EU Common Agricultural Policy. Science 2019, 365, 449-451. [CrossRef]

45. Ronchi, S.; Salata, S.; Arcidiacono, A.; Piroli, E.; Montanarella, L. Policy instruments for soil protection among the EU member states: A comparative analysis. Land Use Policy 2019, 82, 763-780. [CrossRef]

46. Barling, D.; Duncan, J. The dynamics of the contemporary governance of the world's food supply and the challenges of policy redirection. Food Secur. 2015, 7, 415-424. [CrossRef]

47. Havinga, T.; Van Waarden, F.; Casey, D. Changing Regulatory Arrangements in Food Governance. In The Changing Landscape of Food Governance: Public and Private Encounters; Havinga, T., van Waarden, F., Casey, D., Eds.; Edward Elgar Publishing: Cheltenham, UK, 2015; pp. 13-18.

48. Pelkmans, J.; Renda, A. Does EU Regulation Hinder or Stimulate Innovation? CEPS Special Report. 2014. Available online: https://core.ac.uk/download/pdf/76797108.pdf (accessed on 7 May 2020).

49. Ecolabel Index. 2020. Available online: http://www.ecolabelindex.com/ (accessed on 4 May 2020).

50. Castka, P.; Corbett, C.J. Governance of Eco-Labels: Expert Opinion and Media Coverage. J. Bus. Ethics 2014, 135, 309-326. [CrossRef]

51. Messer, K.D.; Costanigro, M.; Kaiser, H.M. Labeling Food Processes: The Good, the Bad and the Ugly. Appl. Econ. Perspect. Policy 2017, 39, 407-427. [CrossRef] 
52. Van Der Ven, H.; Rothacker, C.; Cashore, B. Do eco-labels prevent deforestation? Lessons from non-state market driven governance in the soy, palm oil, and cocoa sectors. Glob. Environ. Chang. 2018, 52, 141-151. [CrossRef]

53. Derkx, B.; Glasbergen, P. Elaborating global private meta-governance: An inventory in the realm of voluntary sustainability standards. Glob. Environ. Chang. 2014, 27, 41-50. [CrossRef]

54. Behringer, J.; Feindt, P.H. How Shall We Judge Agri-Food Governance? Legitimacy Constructions in Food Democracy and Co-Regulation Discourses. Politics Gov. 2019, 7, 119. [CrossRef]

55. Darnall, N.; Ji, H.; Vazquez-Brust, D. Third-Party Certification, Sponsorship, and Consumers' Ecolabel Use. J. Bus. Ethics 2016, 150, 953-969. [CrossRef]

56. Waldman, K.B.; Kerr, J.M. Limitations of Certification and Supply Chain Standards for Environmental Protection in Commodity Crop Production. Annu. Rev. Resour. Econ. 2014, 6, 429-449. [CrossRef]

57. Auld, G. Constructing Private Governance: The Rise and Evolution of Forest, Coffee, and Fisheries Certification; Yale University Press: New Haven, CT, USA, 2014.

58. Astill, J.; Dara, R.; Campbell, M.; Farber, J.M.; Fraser, E.D.; Sharif, S.; Yada, R.Y. Transparency in food supply chains: A review of enabling technology solutions. Trends Food Sci. Technol. 2019, 91, 240-247. [CrossRef]

59. Kos, D.; Kloppenburg, S. Digital technologies, hyper-transparency and smallholder farmer inclusion in global value chains. Curr. Opin. Environ. Sustain. 2019, 41, 56-63. [CrossRef]

60. Pardey, P.G.; Chan-Kang, C.; Dehmer, S.P.; Beddow, J.M. Agricultural R\&D is on the move. Nature 2016, 537, 301-303. [CrossRef] [PubMed]

61. Mylan, J.; Geels, F.W.; Gee, S.; McMeekin, A.; Foster, C. Eco-innovation and retailers in milk, beef and bread chains: Enriching environmental supply chain management with insights from innovation studies. J. Clean. Prod. 2015, 107, 20-30. [CrossRef]

62. Herrero, M.; Thornton, P.K.; Mason-D’Croz, D.; Palmer, J.; Benton, T.G.; Bodirsky, B.L.; Bogard, J.R.; Hall, A.; Lee, B.; Nyborg, K.; et al. Innovation can accelerate the transition towards a sustainable food system. Nat. Food 2020, 1, 266-272. [CrossRef]

63. Candel, J.; Pereira, L.M. Towards integrated food policy: Main challenges and steps ahead. Environ. Sci. Policy 2017, 73, 89-92. [CrossRef]

64. Bhaduri, A.; Ringler, C.; Dombrowski, I.; Mohtar, R.; Scheumann, W. Sustainability in the water-energy-food nexus. Water Int. 2015, 40, 723-732. [CrossRef]

65. To, H.; Grafton, R.Q. Oil prices, biofuels production and food security: Past trends and future challenges. Food Secur. 2015, 7, 323-336. [CrossRef]

66. Obersteiner, M.; Walsh, B.; Frank, S.; Havlík, P.; Cantele, M.; Liu, J.; Palazzo, A.; Herrero, M.; Lu, Y.; Mosnier, A.; et al. Assessing the land resource-food price nexus of the Sustainable Development Goals. Sci. Adv. 2016, 2, e1501499. [CrossRef] [PubMed]

67. Brunori, G.; Galli, F.; Barjolle, D.; Van Broekhuizen, R.; Colombo, L.; Giampietro, M.; Kirwan, J.; Lang, T.; Mathijs, E.; Maye, D.; et al. Are Local Food Chains More Sustainable than Global Food Chains? Considerations for Assessment. Sustainability 2016, 8, 449. [CrossRef]

68. MacDiarmid, J.I. Seasonality and dietary requirements: Will eating seasonal food contribute to health and environmental sustainability? Proc. Nutr. Soc. 2013, 73, 368-375. [CrossRef] [PubMed]

69. Caron, P.; De Loma-Osorio, G.F.Y.; Nabarro, D.; Hainzelin, E.; Guillou, M.; Andersen, I.; Arnold, T.; Astralaga, M.; Beukeboom, M.; Bickersteth, S.; et al. Food systems for sustainable development: Proposals for a profound four-part transformation. Agron. Sustain. Dev. 2018, 38, 41. [CrossRef] [PubMed]

70. Lamine, C.; Magda, D.; Amiot, M.-J. Crossing Sociological, Ecological, and Nutritional Perspectives on Agrifood Systems Transitions: Towards a Transdisciplinary Territorial Approach. Sustainability 2019, 11, 1284. [CrossRef]

71. OECD; FAO; UNCDF. Adopting a Territorial Approach to Food Security and Nutrition Policy; OECD Publishing: Paris, France, 2016. [CrossRef]

72. Malak-Rawlikowska, A.; Majewski, E.; Wąs, A.; Borgen, S.O.; Csillag, P.; Donati, M.; Freeman, R.; Hoàng, V.; Lecoeur, J.-L.; Mancini, M.C.; et al. Measuring the Economic, Environmental, and Social Sustainability of Short Food Supply Chains. Sustainability 2019, 11, 4004. [CrossRef]

73. Smith, J.; Lang, T.; Vorley, B.; Barling, D. Addressing Policy Challenges for More Sustainable Local-Global Food Chains: Policy Frameworks and Possible Food "Futures". Sustainability 2016, 8, 299. [CrossRef] 
74. Springmann, M.; Clark, M.; Mason-D’Croz, D.; Wiebe, K.D.; Bodirsky, B.L.; Lassaletta, L.; De Vries, W.; Vermeulen, S.J.; Herrero, M.; Carlson, K.M.; et al. Options for keeping the food system within environmental limits. Nature 2018, 562, 519-525. [CrossRef]

75. MacDiarmid, J.; Douglas, F.; Campbell, J. Eating like there's no tomorrow: Public awareness of the environmental impact of food and reluctance to eat less meat as part of a sustainable diet. Appetite 2016, 96, 487-493. [CrossRef]

76. Stoll-Kleemann, S.; Schmidt, U.J. Reducing meat consumption in developed and transition countries to counter climate change and biodiversity loss: A review of influence factors. Reg. Environ. Chang. 2016, 17, 1261-1277. [CrossRef]

77. Van Der Weele, C.; Feindt, P.H.; Van Der Goot, A.; Van Mierlo, B.; Van Boekel, M.A. Meat alternatives: An integrative comparison. Trends Food Sci. Technol. 2019, 88, 505-512. [CrossRef]

78. Cingiz, K.; Wesseler, J. Opportunities and the policy challenges to the circular Agri-Food system. In EU Bioeconomy Economics and Policies: Volume II. Palgrave Advances in Bioeconomy: Economics and Policies; Dries, L., Heijman, W., Jongeneel, R., Purnhagen, K., Wesseler, J., Eds.; Palgrave Macmillan: Cham, Switzerland, 2019; pp. 293-318. [CrossRef]

79. Kirchherr, J.; Reike, D.; Hekkert, M. Conceptualizing the circular economy: An analysis of 114 definitions. Resour. Conserv. Recycl. 2017, 127, 221-232. [CrossRef]

80. Korhonen, J.; Honkasalo, A.; Seppälä, J. Circular Economy: The Concept and its Limitations. Ecol. Econ. 2018, 143, 37-46. [CrossRef]

81. Jurgilevich, A.; Birge, T.; Kentala-Lehtonen, J.; Korhonen-Kurki, K.; Pietikäinen, J.; Saikku, L.; Schösler, H. Transition towards Circular Economy in the Food System. Sustainability 2016, 8, 69. [CrossRef]

82. COM. A new Circular Economy Action Plan: For a Cleaner and More Competitive Europe. COM/2020/98 Final. 2020. Available online: https:/eurlex.europa.eu/legalcontent/EN/TXT/?uri=COM:2020:98:FIN (accessed on 13 May 2020).

83. COM. The European Green Deal. COM/2019/640 Final. 2019. Available online: https://eur-lex.europa.eu/ legal-content/EN/TXT/?uri=CELEX:52019DC0640 (accessed on 8 May 2020).

84. COM. The European Union and the United Kingdom-Forging a New Partnership. Available online: https://ec.europa.eu/info/european-union-and-united-kingdom-forging-new-partnership_en (accessed on 22 May 2020).

85. Matthews, A. The Potential Implications of a Brexit for Future EU Agri-food Policies. EuroChoices 2016, 15, 17-23. [CrossRef]

86. Jones, E. Old Divisions Threaten Europe's Economic Response to the Coronavirus. 6 April 2020. Foreign Affairs. Available online: https://www.foreignaffairs.com/articles/europe/2020-04-06/old-divisions-threateneuropes-economic-response-coronavirus (accessed on 25 June 2020).

87. Weible, C.M.; Nohrstedt, D.; Cairney, P.; Carter, D.P.; Crow, D.A.; Durnová, A.P.; Heikkila, T.; Ingold, K.; McConnell, A.; Stone, D. COVID-19 and the policy sciences: Initial reactions and perspectives. Policy Sci. 2020, 53, 225-241. [CrossRef]

88. Lucas, T.; Horton, R. The 21st-century great food transformation. Lancet 2019, 393, 386-387. [CrossRef]

89. Béné, C.; Oosterveer, P.; LaMotte, L.; Brouwer, I.D.; De Haan, S.; Prager, S.D.; Talsma, E.F.; Khoury, C.K. When food systems meet sustainability-Current narratives and implications for actions. World Dev. 2019, 113, 116-130. [CrossRef]

90. Pradhan, P.; Costa, L.; Rybski, D.; Lucht, W.; Kropp, J.P. A Systematic Study of Sustainable Development Goal (SDG) Interactions. Earths Future 2017, 5, 1169-1179. [CrossRef]

91. Harris, A. WHO: World Health Organization. Charlest. Adv. 2011, 12, 54-56. [CrossRef]

92. UNEP. Frontiers 2016: Emerging Issues of Environmental Concern. 2016. Available online: https:// www.unenvironment.org/resources/frontiers-2016-emerging-issues-environmental-concern (accessed on 28 April 2020).

93. Friel, S.; Schram, A.; Townsend, B. The nexus between international trade, food systems, malnutrition and climate change. Nat. Food 2020, 1, 51-58. [CrossRef] 
94. Barling, D.; Sharpe, R.; Gresham, J.; Mylona, K. Characterisation Framework of Key Policy, Regulatory and Governance Dynamics and Impacts upon European Food Value Chains: Fairer Trading Practices, Food Integrity, and Sustainability Collaborations. The VALUMICS Project "Understanding Food Value Chains and Network Dynamics" Funded by EU Horizon 2020 G.A. No Deliverable D3.3; University of Hertfordshire: Hatfield, UK, 2018; 416p. [CrossRef]

95. IPES Food (International Panel of Experts on Sustainable Food Systems). Towards a Common Food Policy for the European Union: The Policy Reform and Realignment that is Required to Build Sustainable Food Systems in Europe. IPES Food (International Panel of Experts on Sustainable Food Systems). 2019. Available online: http://www.ipes-food.org/_img/upload/files/CFP_FullReport.pdf (accessed on 22 May 2020).

96. Naja, F.; Hamadeh, R. Nutrition amid the COVID-19 pandemic: A multi-level framework for action. Eur. J. Clin. Nutr. 2020, 74, 1117-1121. [CrossRef]

(C) 2020 by the authors. Licensee MDPI, Basel, Switzerland. This article is an open access article distributed under the terms and conditions of the Creative Commons Attribution (CC BY) license (http://creativecommons.org/licenses/by/4.0/). 